\section{British copyright protection law in sight in new parliament}

\section{London}

THE newly elected Conservative government is expected to devise new copyright and patent legislation early in the next session of parliament, providing protection from piracy for British high-technology industries.

The proposed legislation was outlined in the spring of 1986 with the publication of a white paper (policy document) Intellectual Property and Innovation but was jettisoned from the programme of the last parliamentary session for lack of time in the run-up to last week's general election.

Advisers at the Department of Trade and Industry, responsible for framing legislation, were relieved at the respite, because of the complexity of the bill, but continued to work on it as legislation would be necessary irrespective of the political flavour of the new government.

The legislation, according to the government when the white paper was published, "will improve the intellectual property system in the United Kingdom to the benefit of innovative talent and those who enjoy and use the fruits of these talents".

The most recent attempts to study the inadequacies of current legislation began with the committee headed by Mr Justice Whitford, which published its report, Copyright and Designs Law, in 1977. The government, which changed from Labour to Conservative in the interim, did not respond until four years later, in the form of a green paper (discussion document) outlining the problems facing the "reform of the law relating to copyright, designs and performers' protection".

By that time, advances in computing, videotape recording and photocopiers since 1977 made many of the government responses to Whitford obsolete. But the industries under threat could not wait for further studies and demanded immediate action. To satisfy the film industry, an amendment to existing legislation was introduced in 1983 making it a crime to handle, sell or process counterfeit video material.

The British computer industry demanded the same immediate protection. Most of the major software and hardware companies formed a lobby group called the Federation Against Software Theft (FAST). The federation, whch soon claimed that more than $£ 150$ million a year was being lost through illegal copying and commercial piracy, much of it in the Far East, had some success in 1985 with the passing of an amendment to the Copyright Act of 1956 , giving protection to computer programs and devising a range of penalties for the offenders. The possession, sale or hire of pirated software could mean a fine up to $£ 2,000$ or imprisonment for up to two months for each offence.

The new legislation package now being drafted will attempt to protect the copyright owners from loss of revenue on a very wide front, hence the complexity of the legislation. It includes the prohibition of home copying of computer programs and video tapes, a 10 per cent levy on audio cassette tapes, more copyright protection for computer programs and the extension of film/broadcasting copyright to television programmes beamed by satellite.

But vested interests within these industries are pressing for even stronger

\section{London}

FANG Lizhi, the astrophysics professor who was expelled from the Chinese Communist Party last January, has been refused permission to visit the United States this year. Declining an invitation for a month-long visit of lectures and joint research at the University of California's Lick Observatory, Fang explained that an official of the Chinese Academy of Sciences had told him that his presence "might raise instabilities among Chinese students studying in the United States"

Fang has, however, been allowed to attend an astrophysics conference in Italy, and is due shortly in Britain for a similar meeting in Cambridge. His situation seems to reflect a fluid situation in the official Chinese attitude to academic dissent. Officially, the Chinese line is, once again, to allow a hundred thoughts to contend, and although, in January, Fang was relieved of his post at the University of Science and Technology in Hefei, there was no official objection when the Chinese Academy of Sciences found him a research post in Beijing. On the other hand, the student disturbances of last December have left the authorities wary of anything that could lead to further unrest in the universities. Furthermore, the Chinese students in the United States have already come under the watchful eye of the home government, by issuing an open letter expressing their concern about events in China. Although, according to He Dongchang, the Vice-Minister of Education, the signatories of the letter had not understood the domestic situation properly, Fang's presence in the United States would clearly constitute too great a risk. measures. The music and film industries have been seeking a levy on blank video cassettes and players as compensation for lost revenue; the computer industry wants a simpler and less burdensome method of challenging copyright. And, because of the amount of revenue allegedly lost through illegal copying, FAST will demand that the copyright holder should have the sole right to determine whether a product can be hired or not.

The high-technology industries will also seek protection under international agreements to stifle organized piracy at its source. The Berne Copyright Convention, now 100 years old, provides some copyright protection in more than 75 countries, but many of the developing nations in the Far East are either not signatories or ignore the rules and so remain the primary sources of counterfeit product.
Bill Johnstone

\title{
Chinese scientist refused leave to visit United States
}

Official Chinese explanations of the December strikes put the blame more and more on Fang: in a recent 'dialogue' with students at the University of Science and Technology (subsequently reported at length in the People's Daily), the deputy secretary of the University's Party Committee stated unequivocally that "it was Fang who encouraged students to strike". Fang himself is saying as little as possible about the events leading up to his expulsion from the party, and, although, during his visit to Italy, he gave an interview for Japanese television, he kept his remarks low-key and tried not to commit himself about his role in the disturbances.

Although students throughout China have endorsed ritual condemnations of Fang's political errors, he still seems to enjoy some sympathy and support in student circles. At the end of last month, students of Beijing University elected Fang's wife, Li Shuxian, an associate professor of physics, as a delegate to the local district People's Congress. These congresses are the only government body elected by popular vote (in this case, three candidates being elected from a slate of four, nominated by the students). Li Shuxian received 8,639 votes out of a total of 9,689 , with the second and third most popular candidates receiving 5,473 and 5,264 respectively. There was a 90 per cent turnout, which Chinese sources describe as "unprecedented". In recent years, turnout has twice been so low that the election has had to be repeated a second time (and in one case a third time) to secure a mandate. Officials of Beijing University attribute the new high turn out to the students having "gradually increased their awareness of elections". 